\section{Tryptophol Metabolism by a Species of Arthrobacter ${ }^{\dagger}$}

\section{Yôsuke Mino}

\section{Division of Entomology and Plant Physiology, Obihiro Zootechnical University, Obihiro, Japan}

Received June 2, 1973

Tryptophol (T-ol) production from Tryptophan (Try) by various organisms has been reported by many workers. ${ }^{6 \sim 17 !}$ Rayle and Purves ${ }^{18 !}$ demonstrated the conversion of $\mathrm{T}$-ol to indole-3-acetic acid (IAA) using cucumber seeldings. Recently Libbert et al. ${ }^{191}$ confirmed the presence of this system in both pea stem homogenates and epiphytic bacteria. However as yet we have only a few studies on the inducible nature and the mechanism of T-ol oxidation system of bacteria. Arthrobacter sp. was found to decompose T-ol and utilized it as a sole source of carbon and nitrogen. This paper describes an inducible oxidation system of $\mathrm{T}$-ol in this bacterium.

The bacterial culture in the polypeptone or succinate medium was carried out as described previously. ${ }^{11}$ Bacterial concentration and oxygen uptake were determined using a spectrophotometer and a Warburg manometer, respectively." Indole-3-acetaldehyde (IAAld) was liberated from IAAld $\cdot \mathrm{NaHSO}_{3}$ with $\mathrm{Na}_{2} \mathrm{CO}_{3}$ and extracted with ether. For the induction of the enzymes by an inducer, the cells from the polypeptone or succinate medium were suspended in $10 \mathrm{ml}$ of phosphate buffer $(1 / 15 \mathrm{M}, \mathrm{pH} 6.8)$ containing $1 \mathrm{~mm}$ inducer. After $2 \mathrm{hr}$ incubation at $30^{\circ} \mathrm{C}$, the cells were collected and assayed for the enzyme activities. The reaction mixture was composed of $2 \mathrm{ml}$ of the bacterial suspension in the main chamber and $0.2 \mathrm{ml}$ of $10 \mathrm{~mm}$ substrate in the side arm. The identification of oxidation products was carried out as follows. Ten milliliters of the phosphate buffer containing T-ol induced cells (concentration, 2.0 O.D.500) were placed in the main chamber of a Thunberg tube and $1 \mathrm{ml}$ each of $10 \mathrm{~mm}$ methylene blue $(\mathrm{Mb})$ and $\mathrm{T}$-ol in the side arm. After evacuation, the reaction mixture was incubated at $30^{\circ} \mathrm{C}$ for $20 \mathrm{~min}$ followed by centrifugation. The supernatant was adjusted to $\mathrm{pH}$ 3.0 with $1 \mathrm{~N} \mathrm{HCl}$ and extracted by ether. The condensed organic layer was subjected to paper chromatography using Toyo filter paper No. $51 \mathrm{~A}$. The same experiment was conducted using IAAld in the presence and absence of $\mathrm{Mb}$. Spray reagents used were $0.1 \%$ ferric chloride in $1 \mathrm{~N} \mathrm{HCl}(\mathrm{Fe}), 0.5 \%$ p-dimethylamino-

$\uparrow$ Studies on the Destruction of Indole-3-acetic Acid by a Species of Arthrobacter. Part VI. See References 1 5). benzaldehyde in $1 \mathrm{~N} \mathrm{HCl}(\mathrm{DAB})$ and $0.5 \% p$-dimethylaminocinnamaldehyde in $1 \mathrm{~N} \mathrm{HCl}$ (DAC).

As shown in Fig. 1, T-ol was oxidized by non-induced cells only after an induction of about $30 \mathrm{~min}$, while $\mathrm{T}$-ol was oxidized without lag time by $\mathrm{T}$-ol induced cells. T-ol oxidation by non-induced cells was not observed in the presence of $1 \mathrm{~mm}$ chloramphenicol or dihydrostreptomycin during the first $2 \mathrm{hr}$. This suggests that $\mathrm{T}$-ol oxidizing system was de nove syn.

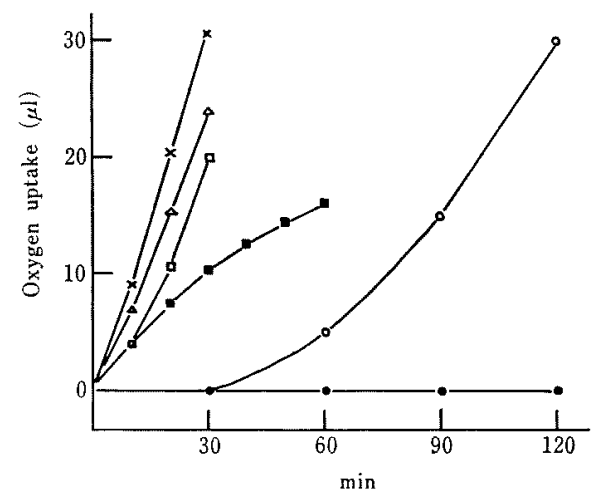

Frg. 1. T-ol Oxidation. Bacterial concentration was 0.5 O.D.500.

$\mathrm{O}-\mathrm{O}$, cells from succinate medium; $-\mathbf{-}$, cells from succinate medium in the presence of $1 \mathrm{~mm}$ chloramphenicol or dihydrostreptomycin; $x-x, T$-ol induced cells from polypeptone medium; $\triangle-\Delta, \mathrm{x}$-Try induced cells from polypeptone medium; $\square-\square$, IAAld induced cells from polypeptone medium, and $\mathbf{n}-\mathbf{\square}$, IAAld induced cells from polypeptone medium in the presence of $1 \mathrm{~mm}$ chloramphenicol.

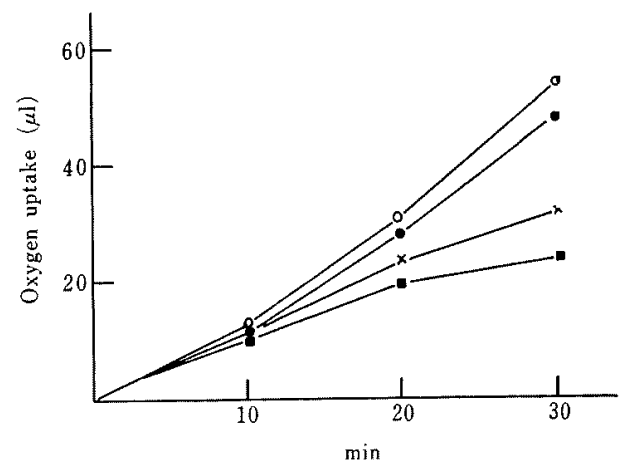

Frg. 2. IAAld Oxidation by T-ol Induced Cells and IAA Oxidation by IAAld Induced Cells.

The induction time was $3 \mathrm{hr}$. Bacterial concentration was 0.5 O.D. 500 .

$\bigcirc-O$, IAAld oxidation by $\mathrm{T}$-ol induced cells; $-\mathbf{0}$, IAA oxidation by IAAId induced cells; $x-x$, IAAld oxidation by $T$-ol induced cells in the presence of $1 \mathrm{~mm}$ chloramphenicol and $-\mathbf{\square}$. IAA oxidation by IAAld induced cells in the presence of $1 \mathrm{~mm}$ chloramphenicol. 
thesized in the cells, as expected for the production of an inducible enzyme. The T-ol oxidizing system was also induced by L-Try and IAAld. Indole-3-lactic acid, IAA, ethanol, acetaldehyde and benzylalcohol were ineffective to the induction of the system. The metabolic path of $\mathrm{T}$-ol was examined by the method of sequential induction As shown in Fig. 2, T-ol induced cells oxidized IAAld, and IAAld induced cells oxidized IAA, respectively, in the presence of chloramphenicol, suggesting that $T$-ol may be oxidized to IAA via IAAld. IAAld and IAA oxidation proceeded almost at the same rate for the first $10 \mathrm{~min}$ in the presence and absence of chloramphenicol, but thereafter the velocity of their oxidation decreased gradually in the presence of chloramphenicol. This might not be attributable to the inhibition of the enzymatic activities by chloramphenicol, but to the instability of the once formed enzymes in the cells. Metabolic products from T-ol and IAAld were also examined paper chromatographically. The $R f$ values and color reactions of two products from $T$-ol were identical with those of authentic IAAld and IAA (Table I). As products from IAAld, only IAA was detected in the presence of $\mathrm{Mb}$, and T-ol and IAA were produced in the absence of $\mathrm{Mb}$. Though the results were not detailed in this paper, these products were identified by paper chromatography and color reactions. In tentative conclusion the metabolic path of T-ol is summarized as following schema: $\mathrm{T}$-ol $\rightleftarrows$ IAAld $\rightarrow$ IAA.

Among the compounds tested, L-Try, IAAld and $\mathrm{T}$-ol were able to induce the $\mathrm{T}$-ol oxidizing enzyme system. In previous papers, ${ }^{1,5}$ IAAld was reported to be formed from L-Try, which was not metabolized to T-ol via indole-3-pyruvic and indole-3-lactic acids in this Arthrobacter. Therefore the induction of this system by L-Try may be attributable to IAAld, but not

\section{Table I. $R f$ Values of Oxidation Products of T-OL, AND AUTHENTIC INDOLE-3-ACETALDEHYDE (IAALD) AND INDOLE-3-ACETIC ACID (IAA)}

Ascending paper chromatography was carried out at room temperature. Color reactions of IAAld and spot 1, and IAA and spot 2 with Fe, DAB and DAC, respectively, were identical.

\begin{tabular}{|c|c|c|c|c|}
\hline \multirow{2}{*}{$\frac{\text { Solvent system }}{\mathrm{BuOH} / \mathrm{HOAc} / \mathrm{H}_{2} \mathrm{O}}$} & \multicolumn{2}{|c|}{ IAAld Spot 1} & \multirow[t]{2}{*}{ IAA } & \multirow[t]{2}{*}{ Spot 2} \\
\hline & & & & \\
\hline$(4: 1: 5)$ & 0.94 & 0.96 & 0.90 & 0.92 \\
\hline $\mathrm{BuOH} / \mathrm{H}_{2} \mathrm{O} / \mathrm{NH}_{4} \mathrm{OH}$ & & & & \\
\hline$(15: 1: 3)$ & & & 0.45 & 0.48 \\
\hline iso-ProOH $/ \mathrm{H}_{2} \mathrm{O}(5: 95)$ & & & 0.88 & 0.86 \\
\hline $\mathrm{EtOH} / \mathrm{H}_{2} \mathrm{O}(7: 3)$ & 0.95 & 0.95 & & \\
\hline iso-ProOH $/ \mathrm{NH}_{4} \mathrm{OH} / \mathrm{H}_{2} \mathrm{O}$ & & & & \\
\hline$(10: 1: 1)$ & 0.89 & 0.89 & 0.58 & 0.57 \\
\hline $\mathrm{BuOH}$ satd. $\mathrm{H}_{2} \mathrm{O}$ & & & 0.70 & 0.70 \\
\hline $\mathrm{BuOH} / \mathrm{EtOH} / \mathrm{H}_{2} \mathrm{O}$ & & & & \\
\hline$(7: 3: 3)$ & & & 0.56 & 0.56 \\
\hline
\end{tabular}

to L-Try per se. Rigaud reported that ethanol dehydrogenase in Rhizobium meliloti converted $\mathrm{T}$-ol to IAAld. ${ }^{17}$ The failure to induce this system by ethanol reflects that $T$-ol oxidation may not be catalyzed by ethanol dehydrogenase, but by specific dehydrogenase system for T-ol metabolism in this Arthrobacter. Agrobacterium tumefaciens, ${ }^{6}$ Phytophthora cactorum ${ }^{20)}$ and Pisum sativum ${ }^{7}$ have been supposed to produce T-ol from IAAld by the enzymatic dismutation. On the contrary, Glombitza ${ }^{131}$ and Rajagopal ${ }^{15 !}$ have claimed that this process is catalyzed by two independent enzyme system. IAA production from IAAld is not considered to be exerted through dismutation, since IAA was formed from IAAld without accompanying $\mathrm{T}$-ol production in the presence of $\mathrm{Mb}$ in this Arthrobacter. In a previous paper, "IAA was shown to be oxidized to completion via catechol. Therefore this bacterium has an inducible complete oxidation system of T-ol as has not been so far reported.

Acknowledgement. The author wishes to express his thanks to Prof. Y. Nishijima, Obihiro Zootechnical University, for his courteous reading of this manuscript.

\section{REFERENCES}

1) Y. Mino, Plant \& Cell Physiol., 9, 169 (1968).

2) Idem, ibid., 9, 205 (1968).

3) Idem, Bot. Mag. Tokyo, 82, 191 (1969).

4) Idem, Plant \& Cell Physiol., 11, 129 (1970).

5) Idem, Physiol. Plant., 23, 971 (1970).

6) J. M. Kaper and H. Veldstra, Biochim. Biophys. Acta, 30, 401 (1958).

7) E. Libbert and K. Brunn, Naturwiss., 48, 741 (1961).

8) P. Larsen, A. Harbo, S. Klungsöyr and T. Aasheim, Physiol. Plant., 15, 552 (1962).

9) F. Wightam, Colloq. Intern, Centre Natl. Rech. Sci., 123, 191 (1963).

10) S. Klungsöyr, ibid., 123, 213 (1963).

11) F. Lingens and W. Göbel, Z. Physiol. Chem., 342, 1 (1965).

12) K.W.Glombitza, Ber. Deut. Bot.Ges, 78, 83(1965),

13) Idem, Experimentia, 23, 101 (1967).

14) T. Hartmann and K. W. Glombitza, Arch. Microbiol., 56, 1 (1967).

15) R. Rajagopal, Physiol. Plant., 21, 1076 (1968).

16) E. Libbert, E. Fischer, A. Drawert and R. Schröder, ibid., 23, 278 (1970).

17) J. Rigaud, ibid., 28, 160 (1973).

18) D. L. Rayle and W. K. Purves, Plant Physiol,, 42, 520 (1967).

19) E. Libbert, R. Schröder, A. Drawert and E. Fischer, Physiol. Plant., 23, 287 (1970).

20) F. J. Schwinn, Phytopathol, Z., 54, 162 (1965). 